\title{
IAMJ
}

INTERNATIONAL

AYURVEDIC

MEDICAL JOURNAL

\section{CONCEPT OF ANTIDOTES V/S PRATIVISHA IN AYURVEDA - A REVIEW ARTICLE}

\author{
Sunil Kumar ${ }^{1}$, Swatika \\ ${ }^{1}$ Assistant Professor, Dept. of Agad Tantra, National College of Ayurveda, Barwala, Haryana, India \\ ${ }^{2}$ M.D. Scholar, Dept. of Dravya Guna \\ Sri Ganganagar College of Ayurvedic Science and Hsopital, Rajasthan - 335002, India
}

Corresponding Author: sunilbams20@gmail.com

https://doi.org/10.46607/iamj4309102021

(Published Online: October 2021)

Open Access

(C) International Ayurvedic Medical Journal, India 2021

Article Received: 11/10//2021 - Peer Reviewed: 20/10/2021 - Accepted for Publication: 22/10/2021

\section{Check for updates}

\section{ABSTRACT}

Ayurveda is a traditional system of medicine with historical roots in the Indian subcontinent. It is one of the most technical medical systems in the world with an extended record of scientific experience. Ayurveda tells the way of life and how to live healthily and stay happy. It has eight prime branches of medicine. Agada tantra is one of the specialized divisions of Ayurveda that offer scrupulously thorough information about animate and non-animated poisons and methods of removal of these poisons from the body. It chiefly advocates different antidotes for equipment that are poisonous to the human body. There are various ancient books which have relation regarding the Toxicology Agada tantra in which we can get references regarding the above mentioned and treated as such with Antidotes. Antidotes are the substances used to counteract or deactivate the effects of poison. Poison may be by plant, or through animal bites like snake bites etc., agricultural poisons, poisonous metals and minerals etc. There are mainly two types of poison mentioned in Ayurveda, are Sthavar visha and Jangham visha., Common antidote in Ayurveda is Swarna, Ghrita, Godudha and Madhu etc. antidote plays important role in the treatment of poisoning which we can see in the current paper, the main moto of doctor is to save the patient's life. In Ayurveda, our Acharyas mentioned the different types of poisonous substances and their antidote under Visha Chikitsa references. The concept of Prativisha which is existed since ancient time needs to be supplemented, explained, refurbish and narrate for proper treatment. So, this article aims to collect the references of curative and preventive measures of poisoning. 
Keywords: Visha, Antidotes, Vagbhatta, Vishavaidya jyotsnika

\section{INTRODUCTION}

If we see the eight branches of Astaang Ayurveda, Agada tantra is a branch of Ayurveda that deals with the treatment of various poisons. If we see the modern part Toxicology deal with a variety of poisons- plant, animal origin poisons, etc. and its management. In ancient times it has been a tradition of vishachikitsa that it is to be taught only through guru shishyasampradaya. Hence very extraordinary books were available during that time. Vishavaidyajyotsnika reconfirms its relevance as it narrates about the old tradition of vishavaidya sampradaya along with Mantra chikitsa which was handwritten in the local language Malayalam in Kerala and now also In Kerala folklore practitioners are practising Mantra Chikitsa with efficient results, but it is not validated in the world because of lack of documentation and research. if someone tries to do so then no practitioner come forward to accept that. The word meaning of vishavaidyajyotsnika is the moonlight that gives eternal happiness from heart ${ }^{1}$. If we see the more concept of antidote according to Ayurveda in Vagbhatta it is explained in detail about the use of Prativisha in almost all types of Visha and indicate if the vishavega is in between 5th and 7th vega that we can see according to the symptom of patients. Prativisha possesses Vyavayi Guna, so that act enthusiastically on an existing symptom of the patient and have an affinity for the same system on which visha has suffered.

Various poisons have been described and for their management, different antidotes have been mentioned in texts of vishajyotsnika.
If we see what a toxin is then the answer, we got is a toxin is a substance which when introduced into or applied to the body is capable of injuring health or destroying life. It causes damage to tissues, disease or demise to the organism. "Vishad jannatwama visham" which means the substance that causes vishad (sadness) to the World is called Visha. As humanity becomes despaired at the sight of it, it was called $v i$ sha ${ }^{2}$.visha are classified according to different Achaya's as Sthavar (Plant) and Jangam (Animal) as main classified form. There are various vega's mentioned by acharya's sthavara as 7 vega's by Acharya sushruta and 8 by Acharya Charak and Jangam as Darvikar mandala rajimant vega's. If we see the treatment according to vega of sthavara and jangam visha then we can see they destroy each other, hence patients bitten by Jangama Visha should be administered, Sthavara visha and for sthavara visha (plant poison), janagam visha (animal poison) is to be administered. They can be used in the form of internal and external applications. Prativisha has action opposite to that poison how it acts will be discussed in the Discussion part.

\section{Aim and Objective}

To review the effect of antidote in Visha told in Ayurveda texts

Here are some Ayurveda antidotes mentions in Visha jyotsnika are-

Table 1: Poison and its antidote ${ }^{3}$

\begin{tabular}{|l|l|l|}
\hline S.N. & Poison & Antidotes \\
\hline 1. & Kannampatty & Puzhaparuhi (Hibiscus tiliaceus) \\
\hline 2. & Panasa & Telkada (Heliotrapium indicum), shunti (Zingiber officinale) \\
\hline 3. & Alcohol & Lemon (Citrus limon) \\
\hline 4. & Bhanga (Cannabis sativa) & Bimbi (Coccinia indica) \\
\hline 5. & Aveen (Papaver somniferum) & Root and leaves of mathigni (Datura metel) \\
\hline 6. & Langali (Gloriosa superba) & Root of neeli (Indigofera tintoria) \\
\hline 7. & Nirvisha (Delphinium denudatum) & Maricha (Piper nigrum) \\
\hline
\end{tabular}




\begin{tabular}{|l|l|l|}
\hline 8. & Pashana- sarshapa (Brasica nigra) & Root of neeli (Indigofera tinctoria), mrinalam (Nelumbo nucifera) \\
\hline 9. & $\begin{array}{l}\text { Aaval (Chirivilwa- Holoptelea integrifolia) } \\
\text { and Chitraka (Plumbago zeylanica) }\end{array}$ & $\begin{array}{l}\text { Eranda (Ricinus communis), navaneeta (butter) and shatavari (As- } \\
\text { paragus recemosa) }\end{array}$ \\
\hline 10. & Oral intake of Kupilu (Strychnus nuxvomica) & Kalka of tender leaves of Gunja (Abrus precatoris) \\
\hline 11. & Dhooma patra & Coconut milk \\
\hline 12. & Vatsanabha (Aconitum ferox) & Nirvisha (Delphinium denudatum) \\
\hline 13. & Removing poison from buttermilk and curd & Old unripe mango brine and cotyledon \\
\hline 14. & Taila veerya & Saline water \\
\hline 15. & Parada (Mercury) & Kushmanda (Benincasa hispida) \\
\hline
\end{tabular}

\section{Definition of Prativisha}

Prativisha means which act against visha. It is made up of two words.

Prati + Visha (Means against) (means those destroy body) Prativisha means the medicine which is used for the purpose of pacifying Visha Utpanna Lakashana. Antidotes are a substance that acts specifically to prevent, inhibit, inactivate, counteract, reverse or relieve the achievement or poisonous effect of a toxic agent.

\section{Need of antidote to being used ${ }^{[4-7]}$}

1. If the poison may not have been completely removed by emesis or gastric lavage.
2. If we see the CI, where these procedures are contraindicated like corrosive, strychnine, coma, volatile poisons (petroleum distillates) etc.

3 . The poison is already absorbed.

4. The poison/toxin has been administered by a route other than ingestion.

\section{Universal antidote ${ }^{[8]}$}

The universal antidote is defined as that is used in those cases where the nature of the ingested poisons is unknown or where it is suspected that a combination of two or more poisons has been taken. It consists of a mixture of readily available substances, as follows

Table 2:

\begin{tabular}{|l|l|l|l|}
\hline Ingredients & Quantity & Type of antidote & Action \\
\hline Powdered charcoal & 2 Parts & Physical & Adsorbs alkaloids \\
\hline Magnesium oxide (milk of magnesia) & 1 Part & Chemical & Neutralize acid \\
\hline Tannic acid & 1Part & Chemical & Precipitate alkaloids, Glycosides and metals \\
\hline
\end{tabular}

\section{Indications of Prativisha ${ }^{[9-10]}$}

1. When the effect of the poison is not subsided by Mantra-Tantra measures and other Aushada Upakarma and drug management.

2. When Visha-Pidita has crossed 5th Vega but has yet not completed 7th Vega. I.e., either in 6th or 7th Visha Vega.

3. the Emergency condition or when all methods of treatment fail, the Prativisha should be administered. Contra-indication of Prativisha ${ }^{[11,12]}$

1. In case of doubt whether a person is having poison or not.

2. Agada administer following the lapse of 7th Visha Vega.

3. When poison is limited to a small area in blood, prativisha should not be administered.
4. In a person who consumes Ruksha Aahar (dry food), the use of prativisha produces disorder of vision, pain in the ear and vatavyadi.

5. Prativisha must not be administered during the rainy period and on cloudy days.

6. Who are in anger, suffering from diseases of Pitta.

7. Who is concerned very much from hunger, thirst, exertion, sun, light, long walk or disease, the pregnant woman, children, the aged person?

8. Those are dry (emaciated greatly) and those anguish from illness of vital organ.

Dose of Prativisha in different poisoned condition ${ }^{\mathrm{s}}$ [11]

1. For the patient of snakebite (Jangham visha)-

Vegetable poisons (Sthaver visha) should be used in the different doses- 
a) Heena Matra (minium dose) - 4 Yava (1 Ratti=125mg)

b) Madhyama Matra (moderate dose) -6 Yava (187.5mg)

c) Uttama Matra (maximum dose)- 8 Yava (250mg)

2. For the patients of insect bite (keeta dansha)- 2 Yava

Matra (62.5mg)

If we see the modern antidote, these are shown as follows-

\begin{tabular}{|l|}
\hline Specific poisoning \\
\hline Acetaminophen/Paracetamol \\
\hline Aspirin \\
\hline Arsenic \\
\hline Anticholinergic poisoning \\
\hline Beta-blockers \\
\hline Benzodiazepines \\
\hline Botulism \\
\hline Calcium channel blockers \\
\hline Copper \\
\hline Chloroquine \\
\hline Lead \\
\hline Mercury \\
\hline Methanol \\
\hline Tricyclic Antidepressant \\
\hline Snakebite \\
\hline Scorpion sting \\
\hline Insulin \\
\hline () Calcium channel blockers \\
\hline
\end{tabular}

\section{DISCUSSION}

We had seen the definition of visha(poison), types of visha and how it acts and the only key for visha treatment is giving amrita in form of Antidot. Let's discuss what are the properties of an antidote. These are the properties of Antidotes-

1. A substance known as Antidotes exert effects by a variety of mechanisms, including forming an inert complex with the toxin, accelerating detoxification of the poison, reducing the rate of conversion of the poison to a more toxic compound, opposite with the poison for essential receptor sites, blocking essential receptors through which the toxic effects are mediated, and bypassing the effect of the poison
3. For scorpion bite- 1 Tila Matra

4. In case of a spider bite- In case of sthavara visha (Plant-based) should not be consumed orally; it should be applied to the skin after Pracchana karma (Incision).

\section{Specific antidote}

NAC

Sodium bicarbonate

BAL

Physostigmine

Glucagon, Insulin

Flumazenil

Guanidine

Atropine, insulin, calcium, lipid emulsion

Penicillamine

Desferrioxamine mesylate

Calcium disodium EDTA

N-Acetyl Penicillamine

Ethanol

Sodium bicarbonate

Anti-snake venom

Anti-Scorpion venom

Glucose/dextrose

Atropine, insulin, calcium, lipid emulsion

2. The use of antidotes depends upon its indications and availability of drugs. Most of the antidotes explained in this text are of plant origin.

If we want to see the exact mode of action of each antidote, we can see do research work during our PG Studies. This is a very good research area for PG scholars. The probable mode of action of each antidote can work with the concept of incompatible action for each other as we have already seen like in day-to-day practice, we can see the alcoholic patients if take excessive alcohol than using lemon juice we can reduce the toxicity of Liquor. Likewise, Neeri Root for Langali poisoning. Ethanol for methanol poisoning etc. we can take each antidote for different poisoning for the research work. Hence an attempt has been made to combine all in one paper. 


\section{CONCLUSION}

Ayurveda knows the importance of Prativisha (Antidote) in counteracting poison belongings. Visha is having like Laghu, Aashu, Sukshma, Vyavayi, Vikashi and so on merits which will penetrate Sukshmatisukshma srotas and act very quickly Sthavarvishas are the types of visha, they have many types, by this article we can identify the sthavarvisha and its stages. We can treat stage-wise and vishadravya wise. In the case of Sthavarvisha poisoning. Prativisha is used by dravyas which will counteract the effect of poison. These prativisha should be used in the form of internal and external applications.

Hence this article had explained some specific antidotes for Stavara and Jangama visha. Classical prativisha (antidote) is to be evaluated systematically with special reference to their effect, dosage, safety and applicability. If we do more research, then it can be validated globally.

\section{REFERENCES}

1. Dr P.V.N.R. Prasad, Illustrated AgadaTantra, Chowkamba Sanskrit series office Varanasi, 3rd edition, 2016, pg no; 2

2. Bapi Ghosh et al "Taxonomical anatomical, cytological and palynological assessment of a germplasm of Indigofera tinctoria L. (Fabaceae): An ayurvedic plant", International Journal of research in Ayurveda Pharmacy, $7 \quad$ (suppl 4), sep-oct 2016. http://www.ijrap.net/admin php/uploads/1662_pdf.pdf [accessed Jun 13, 2018].

3. Dahl JJ, Falk K.et al "Ayurvedic herbal supplements as an antidote to 9/11 toxicity", Alternate Health Med. 2008 Jan-Feb; 14(1):24-8.

4. C.M. Sreekrishnan, Visha vaidya jyotsnika an English translation, oct 2012pg.no;146-147

5. Raja Radha Kantadev, Shodhakalpadruma, 3rd ed. Varanasi; chaukhamba Orientalia, edition 1967 pg 213215.

6. Dr S. R. Inchulkar, Agada Tantra Evam Visha Vighyan, Published by Vaihav Prakashan Raipur, 2017; pg1-44.

7. Paikh's Textbook of Medical Jurisprudence, Forensic Medicine and Toxicology, CBS publisher, New Delhi, 2014; 17: pg no 518-519.

8. Prof. KRS Murthy, Ashtanga Samgraha
9. Paikh's Textbook of Medical Jurisprudence, Forensic Medicine and Toxicology, CBS publisher, New Delhi, 2014; 17: pg no.518-519.

10. Prof. KRS Murthy, Ashtanga Samgraha Uttarsthan Varanasi; chaukhamba Orientalia, 2016; 451: pg no 48-1.

11. Prof. KRS Murthy, Ashtanga Samgraha Vol.3, 2nd ed. Uttarsthan 48/6-8, Varanasi; chaukhamba Orientalia;2016; 452: 48, pg no.22-23.

\section{Source of Support: Nil \\ Conflict of Interest: None Declared}

How to cite this URL: Sunil Kumar \& Swatika: Concept Of Antidotes V/S Prativisha In Ayurveda - A Review Article. International Ayurvedic Medical Journal \{online\} 2021 \{cited October 2021\} Available from: http://www.iamj.in/posts/images/upload/2554_2558.pdf 